Utah State University

DigitalCommons@USU

$11-21-2019$

\title{
Renegotiating Gender Roles and Cultivation Practices in the Nepali Mid-Hills: Unpacking the Feminization of Agriculture
}

\author{
Kaitlyn Spangler \\ Utah State University, kspangler@aggiemail.usu.edu \\ Maria Elsia Christie \\ Virginia Tech, mechristie@vt.edu
}

Follow this and additional works at: https://digitalcommons.usu.edu/envs_stures

Part of the Environmental Studies Commons

\section{Recommended Citation}

Spangler, K., Christie, M.E. Renegotiating gender roles and cultivation practices in the Nepali mid-hills: unpacking the feminization of agriculture. Agric Hum Values (2019). https://doi.org/10.1007/ s10460-019-09997-0

This Article is brought to you for free and open access by the Environment and Society Student Works at DigitalCommons@USU. It has been accepted for inclusion in Environment and Society Student Research by an authorized administrator of DigitalCommons@USU. For more information, please contact digitalcommons@usu.edu.

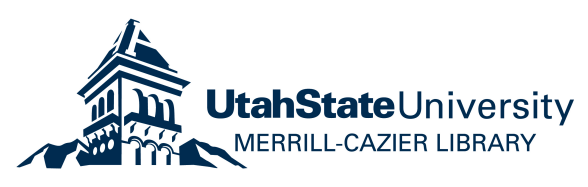




\title{
Renegotiating gender roles and cultivation practices in the Nepali mid-hills: Unpacking the feminization of agriculture
}

Kaitlyn Spangler1, Maria Elisa Christie2

\begin{abstract}
The feminization of agriculture narrative has been reproduced in development literature as an oversimplified metric of empowerment through changes in women's labor and managerial roles with little attention to individuals' heterogeneous livelihoods. Grounded in feminist political ecology (FPE), we sought to critically understand how labor and managerial feminization interact with changing agricultural practices. Working with a local NGO as part of an international, donor-funded research-for-development project, we conducted semi-structured interviews, focus group discussions, and participant observation with over 100 farmers in MidWestern Nepal in 2017. Household structure and headship are dynamic in the context of male out-migration, pushing women to take on new agricultural duties and increasing household labor responsibilities. In this context, decision-making processes related to agricultural management and new cultivation practices illustrate ongoing renegotiations of gender and cultivation practices within and beyond the household. We contend that the heterogeneity of household power dynamics muddies the empowering impacts of migration and emphasize the importance of community spaces as a locus of subjectivity formation and social value. We conclude that FPE can illuminate complexities of power, space, and individual responses to socio-ecological conditions that challenge the current feminization of agriculture framework.
\end{abstract}

Keywords: feminization of agriculture; migration; collective spaces; integrated pest management; feminist political ecology

$\begin{array}{ll}\text { Abbreviations } \\ \text { AVIPMIL } & \text { Asia Vegetable Integrated Pest Management Innovation Lab } \\ \text { CBF } & \text { Community-based facilitator } \\ \text { FGD } & \text { Focus group discussion } \\ \text { FPE } & \text { Feminist political ecology } \\ \text { GDF } & \text { Gender Dimensions Framework } \\ \text { iDE } & \text { International Development Enterprises } \\ \text { IPM } & \text { Integrated pest management } \\ \text { IPMIL } & \text { Feed the Future Integrated Pest Management Innovation Lab } \\ \text { MWR } & \text { Mid-Western Region of Nepal } \\ \text { NGO } & \text { Non-governmental organization } \\ \text { NPR } & \text { Nepalese Rupees } \\ \text { USAID } & \text { United States Agency for International Development } \\ \text { VDCs } & \text { Village Development Committees } \\ \text { WEAI } & \text { Women's Empowerment in Agriculture Index }\end{array}$




\section{Author contact information}

1. Email: kaitlyns@vt.edu, Department of Environment and Society, Utah State University, 5230 Old Main Hill, Logan, UT, 84321

2. Email: mechristie@vt.edu, Center for International Research, Education, and Development, Virginia Tech, 526 Prices Fork Road, Blacksburg, VA, 24061

\section{Author biographies}

1. Kaitlyn Spangler is currently a PhD student at Utah State University after obtaining a master's degree in Geography at Virginia Tech. Her current research focuses on on-farm and landscape diversification within U.S. agricultural systems and the tradeoffs associated with these decision-making processes. She is deeply interested in integrating large-scale quantitative and in-depth qualitative data to more holistically understand farmer livelihoods and agricultural sustainability.

2. Maria Elisa Christie is the Director of the Women and Gender in International Development at the Center for International Research, Education and Development (CIRED) at Virginia Tech. Dr. Christie has more than 30 years of experience in international development. Throughout her career, she has worked with a variety of development, research, and non-governmental agencies around the developing world as well as local, state, and federal governments in the United States and Mexico. Dr. Christie's research focuses on gendered knowledge and space, participatory research methodologies, kitchens and gardens, and women's reciprocity networks. Her publications include Kitchenspace: Women, Fiestas, and Everyday Life in Central Mexico, a book published with the University of Texas Press.

\section{Acknowledgments}

This research would not be possible without the generous support of the American people through the United States Agency for International Development (USAID) and the Feed the Future Integrated Pest Management Innovation Lab (IPMIL) under cooperative agreement number AID-OAA-L-15-00001. The opinions expressed herein belong to the author(s) and do not necessarily reflect the views of USAID. We would like to acknowledge the anonymous reviewers for their suggestions. We are grateful to our field team, including our translator and dear friend, Ms. Lina Jha, and the logistical personnel at iDE Nepal, including Mr. Mukti Devkota, Mr. Lalit Sah, Ms. Roshnee Thapa, Mr. Den Lopchan, Mr. Yubraj Dhakal, and Mr. Bharat Nepal, as well as the agricultural field technician, Mr. Chokra Rai. We would like to thank Dr. Ralph Hall and Dr. Luke Juran for their advice and wisdom and Dr. George Norton for his leadership in the IPMIL. Ultimately, we owe everything to the willingness of the farmers and participants involved in this research. 


\section{Introduction}

Nepal is in the midst of political, economic, infrastructural, demographic, and cultural transformation. In this context, male out-migration is a significant and increasing trend. Men are seeking foreign employment in Gulf countries such as Qatar, United Arab Emirates, and Saudi Arabia and other countries like India and Malaysia, as an alternative and supplementary source of income to their rural livelihoods (Khatiwada et al. 2017; Sunam 2017). Most of these migrants are young men of working age (between 15 to 29 years old). According to the 2011 National Census in Nepal, "absent population" refers to absentees engaged in temporary migration both domestically and abroad (CBS 2012, p. 6). Of the entire Nepali population, $29.8 \%$ are male absentees and $10.9 \%$ are female absentees. Furthermore, male absentees comprise $87.6 \%$ of the absent population compared to $12.4 \%$ of female absentees (CBS 2011; 2012). Labor permits issued to migrant workers by the Government of Nepal have nearly doubled between 2008/09 (219,965 permits) and 2013/14 (519,638 permits) (Khatiwada et al. 2017). This increasing migration influences the gender norms, labor expectations, decision-making processes, and community spaces of sending communities. A growing body of literature examines the migratory implications on changing gendered agricultural practices, referred to as the feminization of agriculture (e.g. Chapagain 2015; Gartaula et al. 2010; Lahiri-Dutt and Adhikari 2016).

Agriculture production is diversifying across Nepal amidst these demographic shifts. Agriculture comprised only $32.5 \%$ of Nepal's economy in 2014 but employed $66.5 \%$ of the population (UNData 2017); therefore, most agricultural production is small-scale. To increase economic return, high-value vegetable crop production is increasingly replacing cereal crop production among smallholder and commercial farmers. Such transitions are largely attributable to international development initiatives (e.g. USAID 2013, 2014, 2018). This research is part of a project funded by the United States Agency for International Development (USAID), the Asia Vegetable Integrated Pest Management Innovation Lab (AVIPMIL) project, that builds on a 12year collaboration between select U.S. universities and an international NGO, International Development Enterprises (iDE), to support production of high-value vegetable crops in Nepal. Integrated pest management (IPM) is defined as an agricultural system that utilizes the economic and ecological context to manage pests while minimizing the use of harmful pesticides through technologies such as pest-resistant crop varieties, beneficial predators of harmful pests, and other crop-specific traps and lures (Norton et al. 2005). AVIPMIL aims to reduce pre- and post-harvest 
losses of crops to increase food security and farm income, improve the health and nutrition of households, promote stakeholder empowerment, and help improve livelihoods of smallholder farmers (USAID 2018). Achieving these goals requires holistic considerations of "technical, institutional, social, cultural, economic, educational, informational, and policy constraints" (Norton et al. 2005, p. 4) as they intersect with gendered dimensions of farmer livelihoods. We address this need through assessing the gendered implications of IPM use associated with AVIPMIL interventions as they relate to broader social processes of labor and agricultural change.

Gendered dynamics and differences within individuals, households, and communities have a significant impact on the success of development programs, including IPM projects (Atreya 2007; Hamilton et al. 2005; Pouratashi \& Iravani 2012; Zselecky et al. 2012). Environmental knowledge and expertise are gendered (Christie et al. 2016; Fortmann 1996), gleaned from people's “daily management of their living landscape" (Rocheleau et al. 1996, p. 6). Failing to incorporate such gendered differences into development objectives can hinder the implementation of these agricultural practices, as well as exacerbate preexisting gender inequalities. A better understanding of the forces that constrain and enable power in daily decision-making and labor can deepen our understanding of the feminization of agriculture as it is entangled within processes of land use change.

This qualitative study addresses two main questions: (i) how does male out-migration affect gendered decision-making and agricultural labor, and (ii) how does the experimentation with and adoption of IPM and other cultivation practices affect gendered workload and decisionmaking processes? IPM use is one among several aspects of agricultural production and changing cultivation practices in this study.

Grounded in a feminist political ecology (FPE) theoretical approach, this paper supports the integration of individuals' knowledge and experience, and their complex uses of space within and beyond the household, into considerations of the feminization of agriculture and processes of rural change. First, we review the debates around the feminization of agriculture and explain our theoretical approach. Next, we describe the Nepali context and our research sites, then discuss our methods. Following that, we present evidence from four communities of the Surkhet District in the Nepali mid-hills and discuss implications of these findings. We close with conclusions at both practical and theoretical levels. 


\section{Deconstructing the feminization of agriculture narrative}

Women have had significant and varying responsibilities in agricultural production throughout history. As Boserup (1970) first argued, with men migrating to look for wage labor, women may take on their abandoned labor roles. Now referred to as the feminization of agriculture, this trend addresses the increased labor participation and decision-making roles of women in agriculture (Gartaula et al. 2010). Scholars have continued to critically examine how farm management roles change in this context (Maharjan et al. 2012; Radel et al. 2012; Su et al. 2016). The concept of feminization originates from its application to poverty trends by Pearce (1978) and has been widely accepted, discussed, and applied in agricultural development literature (e.g. Bieri 2014; Chant 2006; Chilibeck 2004; Deere 2005; Gaddis and Klasen 2014; Lastarria-Cornhiel 2006; Medeiros and Costa 2008). Changes in labor and decision-making responsibilities of women in agriculture can be linked to and understood within several globalizing forces, including increasing trends in export-oriented agriculture, and push and pull migration factors (Lastarria-Cornhiel 2006).

This feminization phenomenon, however, is a sweeping and oversimplified generalization given the gendered complexity of how households divide labor, make decisions, and enact gender roles (Bieri 2014; Chapagain 2015). Considering women as "reserve labor pools" (Radel et al. 2012, p. 116) in the context of male out-migration overlooks the contextual variation and complicated ways gendered beings navigate changes in their livelihoods. Recent literature has called for destabilizing a priori assumptions of the feminization of agriculture (Bieri 2014; Ramamurthy 2010) and further understanding changing dynamics of empowerment "by studying how women are making incremental gains within the existing social order" (LahiriDutt and Adhikari 2016, p. 1002).

The dynamic nature of migration and household composition

Male out-migration is a process of change that affects individuals, households, and communities in overlapping ways. Much of the literature assesses the implications of male outmigration at the household level. However, individual interests of actors within a household do not always reflect the interests of the household as a whole. Rather than a homogenous economic unit, households are "cooperative and conflictual" and do not always act as a "single unit actor" 
(Radel et al. 2013, p. 109). Intra-household resource allocation, patriarchal norms, and labor duties affect how the household acts and operates (Macdonald 1995). Further, organizational changes and different household compositions through male out-migration influence social norms, labor expectations, power relations, and agricultural practices of these changing households (Gartaula et al. 2010; Yabiku et al. 2010).

Problematizing the household as a bounded entity of decision-making complicates previous indicators of the feminization of agriculture. The household is not merely a place of reinforced patriarchal gender norms (as is often portrayed in neoclassical depictions of the household), but a site of men and women as agents of negotiation (Jackson 2007). Male outmigration presents an opportunity for household members to renegotiate their roles and responsibilities. Recent research relies on an increase in female-headed households as an indicator of vulnerability and feminization (Lastarria-Cornhiel 2006; Tamang et al. 2014), but these renegotiations of household roles challenge headship as a measure of vulnerability and decision-making power. To move beyond the limitations of household headship, others argue that the process of feminization should be measured and understood at the individual rather than household level and focus on community-level gender relations as the household expands and adapts to migratory patterns (Lama et al. 2017; Owusu-Afriyie and Nketiah-Amponsah 2014; Ramamurthy 2010). We respond to these calls for a critical investigation of household power dynamics across multiple and interacting scales.

Complexities of labor and managerial feminization

As Bieri (2014) discusses, two positions frame the divergent yet overlapping spheres of the feminization of agriculture: (i) women's labor burden may increase, subjecting women to a greater workload and less available time (Lastarria-Cornhiel 2006); and/or (ii) women may experience greater decision-making power amidst new managerial roles in the absence of their husbands (Deere 2005; Yabiku et al. 2010). Gartaula et al. (2010) describes these two realms of influence as (i) labor feminization and (ii) managerial feminization, respectively. However, discussions of feminization are often rich with theory but lack consistent and reliable evidence, leading to an overuse of the term and a lack of an analytical framework to appropriately 
understand and unpack it (Chant 2006; Bieri 2014). We framed this study to dig deeper into the nuances of both of these processes.

Through labor feminization, women may increasingly "shoulder the responsibility for household survival and respond to economic opportunities in commercial agriculture" (LastarriaCornhiel 2006, p. 1). Some find that women are doing more agricultural work than before their husbands migrated and compared to their non-migrant male counterparts ( $\mathrm{Mu}$ and van de Walle 2011). Other studies find that male out-migration has not directly increased women's agricultural workload but has increased women's managerial roles of farm labor (Maharjan et al. 2013; Radel et al. 2012) or women's ability to seek off-farm employment (Su et al. 2016).

Managerial feminization involves household decision-making in areas such as managing finances, crop production, market engagement, and land management. Several studies have indicated that, as men migrate, women's workloads increase but they do not experience an increase in decision-making authority due to unchanging patriarchal societal structures and gender inequalities (Bhattarai et al. 2015; Lama et al. 2017; Slavchevska et al. 2016; Tiwari and Joshi 2015). Other studies state that independent residence from in-laws, access to off-farm employment, and participation in community groups promote women's autonomy and authority in their households and within the community as their husbands migrate (Abdelali-Martini and Dey de Pryck 2015; Gartaula et al. 2010; Lama et al. 2017; Yabiku et al. 2010). These divergent narratives of labor and managerial feminization illustrate a need to "examine the feminization of agriculture, with greater attention to contradictions and heterogeneity of processes" (Radel et al. 2012, p. 105), as well as to focus on the level at which these dynamics are measured. Changes in norms, expectations, uses of space, identity, and relations of power underpin the social complexities within this debate that must be further explored to inform more equitable and gender-sensitive development programs (Bieri 2014).

Our research is structured and informed by the conceptual relationships related to the feminization of agriculture and changing agricultural practices (Figure 1).

\section{$<<$ Insert Figure 1 about here $>>$}

This figure illustrates our approach beginning with male out-migration, which changes household composition if occurring. This reorganization directly affects the gendered experiences and roles of men and women, as described through labor and managerial aspects of the feminization of agriculture. Household composition is further defined by co-residence with 
in-laws. Labor changes, or labor feminization, are measured through agricultural and household duties. Decision-making changes, referred to as managerial feminization, are measured through agricultural and financial processes. These realms of agricultural and financial decision-making and labor serve as important indicators of power relations. Labor and decision-making impact and in turn are impacted by participation in community groups and mobility, and this participation helps determine changes in agricultural practices. This structural framework connects the literature to our methodology and informs our interpretation of results.

\section{Feminist political ecology: everyday spaces and livelihoods}

To examine the heterogeneity and contradictions of the feminization of agriculture narrative, our study is grounded in the theoretical framework of feminist political ecology (FPE). At odds with the objectives of many modern development projects, FPE argues that the daily performativity and experiences of gender, as one of many overlapping social identities, dictates and interacts with the management of our natural environment (Elmhirst 2011; Mollett 2018; Rocheleau et al. 1996). Development interventions aiming to improve the quality of life for beneficiaries through better technologies, agricultural practices, or infrastructure often fail to consider how gendered livelihoods relate to their objectives (Bhattarai et al. 2015; Fortmann 1996; O’Reilly 2006; Van Houweling 2015). With an FPE framework, we sought to emphasize the heterogeneous experiences of individuals within changing agricultural practices and migration. Through this, we can further understand how, as Nightingale (2011) argues, daily practices and livelihoods shape the spaces and relationships people engage with as they are inextricably connected to ecological processes.

FPE encompasses three themes in gender and environment relations that distinguish different levels of interaction and social influence. The first, gendered knowledge, addresses how scientific and traditional knowledge affects and is affected by the "axes of difference that may shape peoples' experience and understanding of 'environment'” (Rocheleau et al. 1996, p. 10). Second, gendered rights and responsibilities focus on power dynamics of control over and access to natural resources and constructed environments; this includes formal ownership of resources such as land, as well as responsibilities involved in managing resources within households and across communities. Finally, the third theme, gendered environmental activism and grassroots organizing, addresses women's participation in collective groups and the various ways that 
people organize to manage natural resources and share risk amidst scarcity (Nightingale 2006; Rocheleau et al. 1996). We used these three foundational themes of FPE in conjunction with two development tools (described in the methods section) to guide our approach, data collection, and analysis. We hope to contribute to this emerging body of literature that uses FPE to complicate top-down development practices.

\section{The Nepali context}

Employment in Nepal is diverse. The growth of the agricultural sector is inhibited by several factors, including limited access to physical and financial capital, uneven adoption of new agricultural technologies, and health factors impinging on work capacity (Goletti 2013). Men and women engage in increasingly different economic activities, with women employed in agriculture at a higher proportion. According to the World Bank Databank, 83\% of employed females in Nepal in 2017 worked in the agricultural sector, 11\% worked in services, and six percent were employed in industry. In comparison, $60 \%$ of employed males worked in agriculture, whereby $30 \%$ worked in services and 10\% in industry (ILO 2017). These statistics have remained consistent over the past decade, reflecting that men in Nepal have and continued to seek alternatives to agricultural employment. Since merely $20 \%$ of Nepal's landscape is arable, and only $40 \%$ of that is irrigated, adequate agricultural production requires consistent and favorable weather patterns and seasonality. This unreliability often forces laborers to migrate to industrial areas for alternative employment (UNFCO 2011).

Women have long been engaged in agricultural activities as well as in forest management and biodiversity conservation across Nepal, yet their formal political participation and decisionmaking authority has been historically undervalued (Agarwal 2001; Bhattarai et al. 2015; Khadka et al. 2014). Gender, caste, and religion-based inequities, specifically of historically marginalized groups like the Dalits (the lowest caste) and the Muslim population, pervade societal norms and structures in Nepal (UNFCO 2011; USAID 2013) and shape social relations (Sugden et al. 2014). Furthermore, geographical variation across mountainous regions exacerbates social exclusion (Bennett 2005). This is perpetuated by unequal access to natural resources, education, formal land rights, and agricultural technologies (Khadka et al. 2014). Development efforts across Nepal have long called for inclusive, gender-sensitive approaches. 
Research communities

This study is based in the Mid-Western Region (MWR) of Nepal. It is an area of geographic variation; the rugged terrain of the hill and mountain districts impede agricultural production through environmental factors such as flooding, landslides, drought, and crop diseases (UNFCO 2011). Within the MWR, we focus on four communities from the Surkhet District: the then Village Development Committees (VDCs) (before the new constitution in 2017) of Chhinchu, Dasharathpur, Mehelkuna, and Sahare, and within each VDC, the communities of Sanoharre, Goramare, Satmule, and Baghkhor, respectively (Figure 2). These four communities are actively involved in the AVIPMIL project, which has been present in this region since 2013. Residents are from mixed castes, primarily Chhetri, Brahman-Hill, Magar (Janajati), Kami (Dalit), and Damai/Dholi (Dalit), although other castes are also present (CBS 2012). Rice, maize, and wheat are commonly cultivated for household consumption. Vegetables including cabbage, chili, tomatoes, cucumber, bitter gourd, eggplant, cauliflower and cowpeas, are cultivated for both household and commercial purposes depending on available resources and climatic factors.

\section{$<<$ Insert Figure 2 about here $>>$}

Male out-migration is a prevalent trend across these communities. On average, across all four VDCs, $89.8 \%$ of the absent population (approximately 737 individuals) is male. In Chhinchu, $91.1 \%$ of the absent population is male, as is $94.7 \%$ in Dasharathpur. Of the absent population in Mehelkuna and Sahare, $87.7 \%$ and $85.7 \%$ are male, respectively. The prevalence of male out-migration contributes to a skewed average sex ratio of 84.3 males for every 100 females across these four communities according to the 2012 Census (CBS 2012).

\section{Methods}

In response to calls from recent research (e.g. Yabiku et al. 2010), we employed mixed qualitative methodologies to dig deeper into subtle changes in power dynamics amidst male outmigration. During eight weeks of fieldwork between May and July of 2017, our methods included key informant interviews, semi-structured household interviews, focus group discussions (FGDs), and participant observation. The research team consisted of a graduate 
student, a faculty member, a translator and field assistant, and an agricultural field technician. Our local partner, iDE, helped establish relationships and supported logistics, and interviews were conducted through a translator. We recognize the inherent political, cultural, and practical limitations of our positionality as outside researchers within an externally-funded research-fordevelopment project. Together with linguistic challenges, these limited our ability to collect certain sensitive and nuanced data and pursue in-depth inquiries regarding caste and ethnicity. Working with a field team trusted by community members helped mitigate these difficulties.

\section{Participant sampling}

In total, 109 individuals participated in our research activities (see Table 1). Interviews and FGDs were conducted primarily with farmers involved in the IPM project; other participants included NGO personnel, community-based facilitators (CBFs), agricultural field technicians, and government officials.

\section{$<<$ Insert Table 1 about here $>>$}

Participants were selected using both purposive and random sampling. Key informants were selected purposefully and included agro-vets (dealers of agricultural and veterinary products to farmers in their areas) and CBFs at each field site, as well as NGO and government personnel. Farmers were selected randomly from AVIPMIL project records of IPM farmer groups after sorting them into migrant and non-migrant households (based on CBF knowledge). We aimed to talk to farmers that have been involved in IPM project activities since 2013 and who indicated that they had attended IPM trainings and farmer group meetings regularly. Out of the 113 households involved, we randomly sampled 13 to 15 individual farmers - between seven to 11 households - from each of the four communities, reaching 38 households and 57 individual farmers (see Table 1); this included 23 women and 10 men from migrant households and 14 women and 10 men from non-migrant households. A man and a woman from one household were interviewed separately whenever possible and counted as two separate interviews. We conducted participant observation with farmers that had already been interviewed. Separate menonly and women-only FGDs were conducted in each community except in Dasharathpur Goramare, where a men-only FGD was impossible because too few men were available. Other 
than gender, we did not collect individual demographics (specifically caste) from FGD participants.

Data collection and analysis

Through in-depth interactions, we gathered a breadth of data regarding farmer livelihoods and decision-making. Interviews were semi-structured and lasted approximately one hour. We asked key informants about their role in the community, challenges and benefits of this role, and their perspective on project impacts. During household interviews, we engaged participants in deeper conversation with questions informed by the five domains of the Women's Empowerment in Agriculture Index (WEAI) (Alkire et al. 2013): (i) production; (ii) resources; (iii) income; (iv) leadership; and (v) time. We overlapped the WEAI domains with the five dimensions of the Gender Dimensions Framework (GDF) (Rubin et al. 2009): (i) access to resources; (ii) practices and participation); (iii) beliefs and perceptions; (iv) laws, legal rights, policies, and institutions; and (v) power, as a cross-cutting theme. The WEAI is currently one of the most commonly used tools in assessing women's empowerment in development projects. Although designed as a survey tool, recent developments in the WEAI have utilized qualitative research to validate its domain categories and improve the flexibility of its use in different local contexts (Malapit et al. 2019; Meinzen-Dick et al. 2019). Therefore, we used it critically as a bridge between theory and practice to emphasize local perceptions of power which the standard survey WEAI may not be able to capture (O'Hara and Clement 2018). The GDF provides a broad structure to frame the WEAI domains and systematically assess gender roles and relations within USAID programs and projects (Rubin et al. 2009). Its emphasis on multiple spaces of power and influence beyond the household complements the three themes of FPE and extends the spatial scope of the WEAI. Overlaps between domains of the WEAI and the dimensions of the GDF were operationalized through at least one question each. This allowed us to create a breadth of questions relevant both to project-level objectives and theoretical insights of FPE. We then linked these questions and domains to the three themes of FPE (see Appendix table A1).

Interviews addressed four main topics: (i) changes in community gender roles and agricultural practices; (ii) labor distribution, including productive, reproductive, community, and leisure activities; (iii) mapping of places that are important for farmers' livelihoods and IPM 
practices; and (iv) agricultural and financial decision-making processes. Participant observation involved helping farmers with daily tasks, such as collecting fodder for cattle, weeding vegetable plots, transplanting rice, cooking meals, preparing johlmol (an IPM bio-pesticide), or participating in leisure activities. FGDs lasted two to three hours and included a timeline of changes in migration patterns, agricultural production, and gender norms; participatory mapping of gendered spaces of IPM information exchange; and a gendered division of labor chart. Each interview and FGD was audio-recorded. In addition to on-site notetaking (via translation), selected quotes were transcribed word for word.

Data analysis included quantitative and qualitative techniques. Demographic data from household surveys were analyzed in Excel. Notes from each interview, FGD, and field experience were analyzed using 68 conceptual codes in ATLAS.ti, including decision-making patterns, impacts of male out-migration, mobility, and challenges and benefits of IPM. We utilized a mixed process of closed and open coding (Saldana 2016) and grouped codes together in conceptual networks. The overlaps between the WEAI and GDF informed the structure of certain concepts for coding, such as the intersection of intra-household decision-making and access to resources; however, we did not match theses directly with the codes to allow for unexpected concepts to emerge for analysis. We focused on connecting patterns to the three themes of FPE that served as our guiding theoretical framework.

\section{Complexities of the household unit}

Dynamic household composition and headship

Household composition, i.e. who is defined as a household member and who is present in the household, is a dynamic concept. Several factors within the households involved in our study are influenced by the presence of migration. In rural areas, young women are most commonly married to an arranged partner whereby they move from their birth village into their husband's home, often into the home of their parents-in-law, before moving into an independent residence with their husband. We identified migrant and non-migrant households based on the presence or absence of a current migrant (either the household head or a younger male). All 23 migrant households contained one male household head migrant, and four contained one or more additional younger male migrants. We noted households with returned migrants but did not 
classify their households as migrant households. We then separated households into four different groups based on co-residence with in-laws, as emphasized by Gartaula et al. (2010) and Yabiku et al. (2010): (i) non-migrant residing with in-laws (one household); (ii) migrant residing with in-laws (five households); (iii) non-migrant separate from in-laws (14 households); and (iv) migrant separate from in-laws (18 households) (Figure 3). While these groupings are not representative of all households, they proved important to identifying patterns, processes, and impacts of migration.

To engage with the complexities of migrant dynamics more deeply, we focus our analysis primarily on migrant households, both separate and co-residing with in-laws. Therefore, we emphasize changes and patterns within migrant households and experiences of migrant household members in comparison to broader trends across non-migrant households (see Lama et al. 2017). We grouped migrants into two categories, short and long-term migration (Figure 3), based on two factors gleaned from our demographic data: (i) number of months away from home without a break and (ii) if the migrant labor is contractual. Contractual labor is associated with long-term migration that entails more months away from home and less months on break in their home community. Per our classification, long-term migrants spend eight or more months away and spend no more than three months on break per year (often less); these migrants typically migrate to Gulf countries and Malaysia performing labor such as masonry or hotel accounting. Short-term migrants engage in non-contractual labor, often in India, around the planting and harvesting of rice and the Dashain Festival (the largest Hindu festival in Nepal, occurring in October). They are absent for no more than seven months without a break (either between November and June or August and October), performing jobs such as road construction. Our sample includes five households with non-contractual, short-term migrants, 18 households with contractual, long-term migrants, and 15 non-migrant households. There were no clear castebased patterns regarding who engages in contractual or long-term migration. These migration distinctions illustrate the various organizational structures of households and the varying degrees of migration; such distinctions are significant in further understanding how labor and decision-making processes are managed. 


\section{$<<$ Insert Figure 3 about here $>>$}

Formal household headship is often at odds with how power is negotiated across different household structures. Within AVIPMIL project documentation (i.e. demographic records of farmer households), household headship is defined by the traditional norms in Nepal. For nonmigrant households, the household head is often the oldest man, such as the husband or father-inlaw. A woman is noted as the household head only if she is a widow, un-married, lives alone, or if she is the eldest mother-in-law living with her extended family. These formal distinctions of the household head are made in accordance with the universal USAID Feed the Future indicators (as stated by the local agricultural field technician). However, these records do not always match how men and women express their formal and informal roles within the household or the dynamic nature of such roles.

Household composition dictates household headship and power. In migrant households co-residing with their parents or parents-in-law, the father/father-in-law remains the de jure household head during his son's migration. In such cases, the father-in-law's permission is required to perform practices such as planting new crops or taking loans from the cooperative. As men leave temporarily or for long-term work contracts, experiences and understandings of household headship change. Some women self-identify as interim or de facto household heads when their husbands are gone based on their new agricultural and household responsibilities. Thirteen women in migrant households reported that their husband or father-in-law was the household head, despite his short or long-term absence. However, five women residing separately from their in-laws indicated that they are the household head in their husband's absence. A Brahmin woman farmer from Chhinchu Sanoharre stated, "If my husband is home, he is the head. If he's not, I am the head." In all five of these households, the AVIPMIL project records name the husband as the formal head, exemplifying a dissonance between traditional assumptions and intra-household negotiations of power.

\section{Labor feminization}

Challenging the traditional division of labor 
Through changing household dynamics of migration, women and other family members left behind must take on new household and agricultural labor roles. If the father-in-law is present in the household, he generally upholds traditionally male tasks, such as ploughing, as well as other shared tasks such as cutting grasses for cattle feed, irrigation, weeding, and other activities; these roles do not change with migration. However, the roles of the mother-in-law and daughter-in-law whose husband has migrated change and their workloads increase. Women noted that when their husband migrates, they have more work in the household and it is difficult to adjust. Several women indicated that when their husband is home, he helps on the farm and even fetching water or cooking. The father-in-law does not assume such household responsibilities in his son's absence.

The majority of women in migrant households separate from their in-laws stated that their workload increases. Women described that it is easier to manage daily activities when their husbands are home. With men away, women confront new agricultural labor responsibilities through four main overlapping strategies: (i) hiring paid labor; (ii) cultivating less land; (iii) involving their children (mostly their sons); or (iv) taking on these new roles themselves.

Hiring paid labor, most often to plough, was the most common adjustment strategy among women in migrant households separate from their in-laws. Ploughing is a culturally (and sometimes religiously) male task and a symbol of rural masculinities in the traditional gendered division of labor. Most women stated that they are able to do everything on the farm except plough. Primarily older sons learn to plough and assume this role in their father's absence. When children are too young, or in the absence of children, women often hire young male laborers (typically between one and five men) to plough their fields. One Chhetri woman from Chhinchu Sanoharre stated, "That is the one thing men must do!" Women who chose to hire laborers expressed resistance to learning to plough and said hiring others was an affordable option.

Several women stated that they reduced vegetable production after their husband's recent migration because they could not maintain the workload. Women are increasingly in control of and obtaining knowledge about IPM cultivation as their husbands migrate. For example, one male migrant from Dasharathpur Goramare stated he knew nothing about growing vegetables with IPM and would not be involved even while home on break. IPM practices lead to a higher vegetable yield but do not directly increase or decrease labor requirements. The time farmers save not spraying chemical pesticides offsets the time they spend weeding by hand. Proper 
spacing between crops reduces labor by suppressing weed growth, however, vegetable cultivation in addition to other daily tasks can be too much to manage. A Janajati woman farmer from Dasharathpur Goramare said, "We grow for consumption, and if it remains, we sell. If he [her husband] would be here, then we could produce vegetables in a commercial way." However, with remittances providing the primary source of income for the household, women may decide together with their husbands - even if at a distance - to produce less vegetables and thus decrease their workload.

Increasingly, women are assuming male-dominated tasks. At least one woman in each research community ploughs. This act is in direct contradiction to traditional gender norms and is a recent and contentious change. Women who plough do not live with their in-laws, and most live in migrant households. These women are young and often have small children unable to perform heavy labor. In certain situations, the choice to plough was out of necessity, whereby young men were not readily available to hire before the rainy season began. A Dalit woman farmer from Satmule Mehelkuna described her experience: "While ploughing, it is difficult to control the ox and move them in the right direction, as well as move the ploughing tool. My back hurts doing this. My son is only eight years old, so he does not help me. Especially during the rainy season, it is difficult to find someone from the village to help me plough." Another woman added, "Sometimes, we feel like crying. Even when I have money, I cannot do anything." Some women plough because of a lack of alternatives, and others plough in spite of such alternatives. Even with money to hire labor, there are not always enough men available. One Chhetri woman from Chhinchu Sanoharre ploughs her own plot and her neighbor's even though her husband is not a migrant. Her husband is involved in construction work in the community, but she and other community members described him as a drunkard. She learned to plough her plot to decrease reliance on his unpredictable behavior. Another Chhetri woman from Dasharathpur Goramare chose to plough after her husband migrated because she had always wanted to try, but her husband had not approved while he was home. She said, "At first, they said women cannot plough, but they saw me, and now they are used to it. I used to practice ploughing before - when he [her husband] was here - but he didn't allow it and scolded me. Now, he is not here, and I have to plough myself. At the start, it was quite difficult; my body hurt. But now I am used to it." 


\section{Managerial feminization}

Financial decision-making: "It depends on the household"

Male out-migration and household composition complicate decision-making over daily expenses as well as over larger financial endeavors through management of remittances and participation in financial cooperatives. Supplementing revenue from crop sales, remittances provide an injection of income into the household, often monthly. The average remittance amount among migrant households in our study is 18,108 Nepalese Rupees (NPR) (about US\$174) per month. In short-term migration patterns, remittances are less (about 8-10,000 NPR, or US\$77-96) and more sporadic; men and women said the man will send money home "as needed." In long-term migration, men send money home more regularly, every one to three months, and in larger amounts (between 15-50,000 NPR or US\$145-480). In most cases, these remittances comprise the majority of the household income and are used primarily for larger ventures, such as loans and savings, and other expenses, such as school fees and medicine. Managing remittances, large or small, requires new skills women acquire after their husbands migrate; the predictability of this income provides stability for daily and long-term financial endeavors.

Women manage daily expenses - e.g., purchasing supplemental food, oil, salt, tea, and other kitchen supplies - in their households with varying levels of authority. When asked if women have more control over finances in their husbands' absence, most responded with, "It depends on the household." Two Chhetri women farmers in migrant households separate from their in-laws stated that they control all finances, even if or when their husbands are home. Other women stated that they only manage the money when their husbands are gone, maintaining communication with their husbands regarding amounts larger than everyday household expenses daily or several times a week over the phone. Another Janajati woman from Chhinchu Sanoharre consults with her husband before making any purchase, "even if I need a new pair of slippers!" Her husband tells her to spend the money on her own since it is their shared property, but she feels she should ask him before spending the money he earned. Women did not present management of daily household expenses as a direct increase in household control or authority; rather, they said it was simply easier for them to manage these purchases if their husbands were not present or able to do so. 
Income from selling agricultural products such as vegetables or milk are used for smaller household expenses. Production and sale of vegetables also provide farmers who do not migrate the opportunity to earn extra income, given adequate access to land, water, and IPM inputs. Both men and women reported that if are able, they go to the market to sell their surplus vegetables. The act of going to the market does not imply control over the income earned.

Both non-migrant and migrant (short and long-term) households make collective decisions regarding larger financial endeavors, such as taking loans or selling their land. Almost every household member indicated that they would need to consult with their spouse or other family members before selling their land, regardless of who formally owns the land and if the man is physically present or not. A Chhetri woman whose husband does not migrate (and was present during the interview) said, "My husband and I will have a conversation if we can sell our land; even he cannot sell by himself!" However, when the father-in-law formally owns the land, women and their husbands both stated that they would have no formal role in its sale. Yet, in the nine households where women owned all or part of their land, they stated they would not sell it without discussing with other household members first. This cooperative process was common across households.

Agricultural decision-making: "When he comes home, then he can decide"

Amidst new cultivation practices and agricultural technologies, as well as changing societal gender norms, dynamics of agricultural decision-making at the household level are also variable. Power dynamics of different household compositions affect how members share knowledge and make land use decisions. If a father-in-law is present in the household, he retains ultimate decision-making authority over land use practices, but other household members hold subtle yet substantial influence. His wife and daughter-in-law, as well as other family members, play a role in suggesting crop varieties and practices other farmers are using, as well as sharing IPM knowledge with the household. This shared knowledge can facilitate experimentation with and adoption of new crops, as well as encourage initial and continued use of IPM. While this does not directly contest formal household headship, these intra-household negotiations illustrate complexities of land use changes and the choices that determine them.

For households separate from their in-laws, migration patterns determine the involvement of available members in agricultural decisions. Both non-migrant and short-term 
migrant households describe choosing what varieties of rice, maize, wheat, and vegetables to grow as a joint endeavor; when both the husband and wife are present, they talk to each other about what and when they will plant. In many long-term migrant households separate from their in-laws, men increasingly undertake decisions regarding migration and other off-farm endeavors, while women at home make decisions regarding the farm. Both men and women explain that the woman at home will make these decisions about what to grow and how to grow it, as well as manage the labor, in his absence; while migrated, he cannot manage both his own work and work back home on the farm, even over phone conversations. A Janajati woman farmer from Chhinchu Sanoharre whose husband has worked abroad for 15 years explains how she became involved in agricultural work and her increasing authority over the process:

Before my husband left, our situation was not very good. He used to do construction labor for other households, like constructing buildings, etc. I was not doing agricultural work at this time. Then, he left for Sudan shortly after getting married, and that's when I started doing agricultural work. So, I have been handling this the whole time since he's been gone ... He has no idea what is going on in the farm, so I am responsible. When he comes home, then he can decide.

Another Chhetri woman from Chhinchu Sanoharre explains that when her husband is gone, she is in charge of the agricultural activities, and she can do everything except plough the field (for which she hires labor). When we spoke with migrant men home on break, they openly described a separation from agricultural decision-making while they are gone. One Dalit man from Satmule Mehelkuna said, "What can I say from there [Qatar]? She will manage herself."

Beyond the household: expanding spaces of decision-making

Financial and agricultural decision-making extends beyond the household and relies on expanding social networks and interactions between men and women. Farmer group meetings serve as community spaces where decisions are made collectively. The farmer groups are community-organized and community-led. The community-based facilitator (CBF), elected by other members, is the liaison between the farmer group and AVIPMIL project personnel. Both 
men and women can be group presidents or CBFs (half of the CBFs and farmer group presidents across our four research sites are women). The groups meet monthly with the CBF to discuss IPM practices, place orders for IPM products through the CBF, conduct savings and credit activities, and decide what crop varieties to grow in each season.

Financial cooperatives provide an increasingly prevalent space for men and women to save household income and take loans for larger purchases. Farmers often belong to multiple groups; only the individual registered in the group can save, often at a fixed rate per month, and formally take out a loan. Cooperatives - established in these communities 15 to 20 years ago provide a place for women and men to manage their finances outside of the home. Several savings and credit groups specifically target women, especially as men are engaging in labor migration. One key informant from a local cooperative network said that the microfinance cooperatives target over $40 \%$ women's participation in each group. These cooperatives aim to increase opportunities for women (and men in joint cooperatives) to save money and access loans, particularly when they would not be able to do so in a formal bank without ownership of land and other assets. Women and men can both save in their own names, and women can save even without their husbands present. Membership in these cooperatives provides a place and opportunity for men and women to go for meetings at least once a month. It publicly establishes women as capable of managing money within and beyond their households and constitutes a socially acceptable reason for increased mobility within the community.

To learn new knowledge-intensive IPM practices, farmers build trusting relationships with the $\mathrm{CBF}$ and each other. Several women said that they talk to the CBF whenever they have issues with pests on their farm or need help with IPM as they attempt to grow new crop varieties from season to season. Figure 4 shows a participatory map from a women's FGD in Dasharathpur Goramare, indicating spaces where participants gather and share information about IPM. Below the cooperative house structure, they drew four spaces of IPM learning and sharing: the seedling nursery, the IPM training site (the circle labeled "IPM"), the demonstration plot in their community, and their monthly IPM cooperative meetings. The map shows both men and women interacting at the seedling nursery and IPM trainings, whereby the demonstration plot and cooperative meetings are drawn as women's spaces only. The physical distinction of these spaces illustrates that social interactions and knowledge sharing processes are site-specific and independently important. 


\section{$<<$ Insert Figure 4 about here $>>$}

Collective agricultural decision-making in these community spaces helps share the risk of trying new agricultural technologies and expands factors that influence crop production to realms beyond the household. Farmers rely on the CBF to bring IPM products to them from the market and help them choose what products they need, want to try, or collectively decide to use. At each meeting, the CBFs will ask the farmer group to order IPM products, e.g., traps, lures, biopesticides, nylon netting, plastic trays for seedlings, etc., and crop varieties to cultivate. The $\mathrm{CBF}$ purchases these products at the market from the local agro-vets, with whom they have an established relationship, and delivers them to the farmers either at the farmer group meetings or at the farmers' homes. A Chhetri woman farmer explained, "If everyone wants one [IPM] resource, such as nylon nets or plastic trays, it is easier to access and cheaper to buy from the CBFs and it decreases the costs in bulk." Therefore, decisions to purchase new products or try different seeds may occur mostly within the farmer group cooperative rather than the household.

Meetings in community spaces also influence caste-related dynamics. Two Chhetri women from Dasharathpur Goramare explained that even though, "We are all from the same blood," caste discrimination is still present in their community. Group meetings will not be held at Dalit or even Janajati homes because those of higher castes, such as Chhetri or Brahmin, cannot enter those lower caste homes or share water or food. However, these casted boundaries are permeable in public group meetings and cooperative spaces, whereby individuals of all castes participate. Members of lower castes are beginning to hold leadership positions in cooperative groups, though most leaders belong to higher castes. Of the 14 Dalit men and women interviewed, only one man held a president position in his savings cooperative while of the six Janajatis interviewed, three women held leadership roles. One Janajati woman said she is president of three separate groups. The four CBFs were all of higher castes: two Chhetri women and two Brahmin men.

Farmers across all four communities stated that women were not directly involved in large-scale agricultural production 10 to 15 years ago. Although women have long been involved in agriculture through activities such as planting, weeding, maintaining house-lot gardens, and performing necessary household duties, neither men nor women interviewed perceived these 
roles as large-scale agricultural responsibilities. Rather, they discussed how women's limited mobility restricted their involvement in agricultural labor and decisions; most women said they could not leave the house without permission. Nonetheless, over the past decade, women have assumed leadership roles and increased participation (not just attendance) in these spaces; one man from Sahare Baghkhor said that he thinks women speak more than men do at their IPM meetings. Women who are leaders in the IPM farmer groups reported that they can speak in front of large groups and are no longer afraid of groups of men, as they were before participating. Men leaders, on the other hand, did not report public speaking as a benefit of their leadership position. Men did not describe any initial difficulty or discomfort in interacting with others in group settings, describing groups primarily as a place of learning new agricultural information. In contrast to men, women members describe that farmer groups allow people to "gather together" and "build confidence" to speak and interact, as well as learn new information about vegetable production.

\section{Discussion}

Our findings point to the complicated nature of household structure and heterogeneous processes of labor and managerial feminization. Viewed through the three distinct themes in FPE, we illustrate the different experiences of individuals across households and communities as they renegotiate gender roles and cultivation practices amidst migration. These complex livelihoods and daily negotiations muddy the empowering or disempowering effects of the feminization of agriculture.

Gendered knowledge

Male out-migration presents an ongoing site of redefining gendered knowledge related to household management and agricultural practices. Young male migrants are increasingly concerned with decisions regarding migration and off-farm income. Thus, women and men that remain in sending communities are more responsible for adjusting to changes in land use and financial management. As they manage fluctuating workloads, the traditionally separate domains of production knowledge between household members becomes more fluid. Women are gaining expertise about vegetable production and IPM in the same spaces as participating men or in place 
of male migrants. While new agricultural responsibilities do not necessarily equate to greater empowerment or agency (and was not expressed this way by farmers), new IPM knowledge is increasingly valued by most present household members as a viable land use strategy and source of income. By sharing this new knowledge with other family members, they are influencing, both directly and indirectly, how their household manages and values their land; these subtle negotiations reveal a trend toward women assuming new roles as capable producers and land managers.

Furthermore, the intrahousehold management of daily expenses, remittances, and larger financial endeavors reflect that men and women are financial agents in the context of migration, adding complexity to previous household-level analyses (e.g. Acharya et al. 2010; Khatri 2017). IPM vegetable production (increasingly within women's domain) supplements household income, while remittances (through male migrant labor) often comprise the majority of household income. Some argue (e.g. O’Hara and Clement 2018) that income from vegetable production is insufficient to increase women's bargaining power, thus reinforcing gendered imbalances in control over finances. However, in the mid-hills where vegetable production is relatively new, these varied sources of income, as well as increasing access to credit and loans through farmer cooperatives, presents an opportunity for women to learn and engage in new realms of financial management. This opportunity does not guarantee they will gain greater access to such funds or authority in its use; yet, as the profitability of IPM vegetable production increases, women's financial knowledge of such income creates space for a shift in household power.

Social spaces, as identified by the farmers in this study, play an integral role in the access to and production of this new knowledge. The IPM practices gleaned through IPM farmer group meetings is often created and mediated by the scientists, NGO personnel, and development practitioners involved in this development project who are from developed countries, universities, or urban centers of Nepal. Our findings illustrate that farmers collectively sort through new scientific information that challenges prior farm management practices to inform and support ongoing decisions about their use of and investment in IPM. These places for collective learning provide farmers, particularly women in the context of male out-migration, the opportunity to interpret, negotiate and accept/reject this information. For this project and these 
IPM technologies to sustainably respond to and support farmers' changing livelihoods, these spaces are crucial to allow local knowledge to guide the development process.

Gendered rights and responsibilities

Women are increasingly renegotiating their changing household and agricultural labor duties amidst migration and new IPM practices. First, household headship and its associated responsibilities do not remain constant through patterns of migration; this inconsistency adds caution to its use as an indicator of power or decision-making (Zhang et al. 2006). De jure household headship often defaults to the eldest man in the household, but de facto household headship varies as migration patterns influence the responsibilities and perceptions of formal and informal decision-making. For example, changing roles of financial management exhibit neither a clear upheaval nor an empowering acquisition of women's control over household finances due to a man's absence in the household. Rather, these duties are continuously contested and negotiated within the context of changing household needs and income streams.

Migration is also driving the extent to which men and women reassess how they cultivate their land, who performs this labor, and how important this is to their overall livelihood; gendered responsibilities for production evolve alongside the need to uphold the survival of their household. Women are enacting increasingly visible control over their land, i.e. ploughing and managing hired workers; these actions challenge traditional gender norms in the mid-hills. Across castes, we find that women are assuming new labor roles for different personal reasons, not solely because they lack sufficient income to hire workers (though this can be the case for some, e.g. Sugden et al. 2014). These decisions, dependent on varying processes of migration, available laborers and time, present men and women with an opportunity to reframe the ways labor and knowledge are separated within and beyond their own household.

Gendered collective action

Participation in the IPM farmer group and other cooperatives creates a public window of opportunity to contest gender norms as men and women engage in collective learning and decision-making. Farmers make decisions at the cooperative, such as what varieties of crops to 
grow or how much money to save, and can troubleshoot pest management issues together. As stated by nearly all participants, women are now more mobile in the community. Some research has found that women's increasing workloads in the context of male out-migration negatively affects the extent to which they can participate in group organizations and community activities (Lama et al. 2017; Lyon et al. 2016). In these communities, however, women from various castes are becoming active members of group meetings and cooperatives and are increasingly elected to leadership roles by their communities. The increasing acceptance of both men and women in these public places - that were once solely controlled by men - is shifting away from the exclusionary gendered participation norms seen throughout Nepal (Agarwal 2001; Giri and Darnhofer 2010; Khadka et al. 2014; Lama et al. 2017).

Development projects aiming to disseminate new agricultural technologies facilitate farmers coming together, e.g., the designation of farmer groups for IPM learning, but often do not emphasize community ownership of these spaces and the value of social interaction. Yet, the ability to form relationships with other farmers, the CBF, and NGO personnel was critical to farmers' active participation and engagement in group meetings and effective use of IPM. Farmers discuss together the successes and drawbacks of IPM on their own plots and decide collectively which crops varieties to plant and which IPM trap or lure to test. Community spaces represent another overlapping realm of decision-making where men and women can reassess gendered norms of participation, mobility, and knowledge, and witness these contestations of traditional gendered power. Therefore, inclusion across caste, ethnicity, class, and other identities is crucial to equitable social change. As argued by Abdelali-Martini and Dey de Pryck (2015), the ability for farmers to gather together and bring women in contact with other women and men from various backgrounds allows solidarity to foster and transform over time. This legitimizes both men's and women's power as capable producers and managers in the public sphere.

\section{Conclusion}

This paper contributes empirical evidence from the hills of Mid-Western Nepal to a discussion of the complex processes of the feminization of agriculture through a critical FPE approach. We aimed to more deeply understand how male out-migration affects gendered decision-making and agricultural labor and how the experimentation with and adoption of IPM 
and other new cultivation practices affects gendered workload and decision-making. With attention to the heterogeneity of social dynamics, we find mixed changes in labor and managerial feminization in the context of male out-migration, complicated by differences in household composition and migration patterns. Labor and managerial changes are interrelated, whereby availability of time and expectations of agricultural workload influence the decision-making and managerial roles women enact. Furthermore, household decision-making is linked to the changing dynamics of community spaces and relates to gender relations within and beyond the household. Renegotiations of gendered roles and subjectivities occur through various and ongoing interactions: discussions between a migrant and their spouse before, during, and after migration; social interactions in community spaces such as group meetings; and intrapersonal calculations in balancing time, labor, desire, and need. These channels of influence over gendered rights, responsibilities, knowledge, and collective action interrelate in dynamic ways and occur across multiple scales.

Participation in public spaces and increasing presence in the community sphere expands boundaries of decision-making that the feminization of agriculture narrative has too narrowly located within the household. This international IPM project - as with many development interventions - was not designed with the explicit intention of promoting social solidarity through farmer group meetings and networks. Yet, the changing collectivism of cooperatives how and why people gather and who has control over the use of these spaces - is integral to the pathways through which men and women may achieve a greater sense of empowerment, either through development interventions or in spite of such interventions (Cornwall 2016; Kabeer 2011; Kabeer and Huq 2010). Increasing trends of male out-migration create opportunities to reconsider the societal norms that dictate how men and women engage together toward more inclusive and community-owned processes. Using the household as a separate unit of analysis within predetermined metrics, such as household headship, neglects daily contestations of gender norms that occur beyond the household. In response to calls for recognizing and incorporating complexities of space and power (e.g. Bieri 2014; Radel et al. 2012), we argue for a re-centering of the feminization of agriculture narrative, in which the individual, household, and community are understood as relational and continuously interactive in forming gendered subjectivities.

By bridging theory and practice in research-for-development, our approach challenges broad assumptions reproduced in the dominant development paradigm of the feminization of 
agriculture to inform more sustainable development interventions. Using the WEAI and the GDF to inform semi-structured, in-depth data collection highlights the need to go beyond numerical indicators of empowerment and agency. This bridge between critical theory and development practice illustrates a methodological pathway to adapting development projects and assessments to local needs and strengthening the ability of practitioners and researchers to respond to local contexts. Emphasizing and understanding the multiple ways individuals move through spaces, engage in decisions, shape their values, and are affected by larger social processes is a crucial yet overlooked piece of equitable development.

Explicit theoretical grounding in FPE as operationalized and informed by two gender and development field tools (WEAI and GDF) fosters a deeper engagement with how development interventions construct and influence generalized narratives - i.e. the feminization of agriculture - of peoples' complicated and changing livelihoods. Gendered knowledge is changing amidst male out-migration. Women are increasingly involved in household financial management, as well as learning, experimenting with, and implementing new agricultural practices, blurring the boundaries between traditional separation of gendered agricultural knowledge. Gendered rights and responsibilities on and off the farm are renegotiated amidst shifts in household composition. Rather than a clear increase or decrease in women's labor duties, the examples of women ploughing, differential management of hired farm labor, and decisions associated with vegetable production, emphasize that these feminization trends are nuanced. Finally, gendered collective action is seen in the shifting demographics and power dynamics of community spaces and collective decision-making; the social value and gender transformative potential of these spaces cannot be overlooked in achieving sustainable development objectives. Impacts of male outmigration on shifting agricultural practices and decision-making cannot be fully understood without considering the influence of these multiple scales. Bringing the critical, multi-scalar lens of FPE to the feminization of agriculture narrative can help us reflect on the relationship between new technologies and socio-ecological challenges. 


\section{References}

Abdelali-Martini, M., and J. Dey de Pryck. 2015. Does the feminisation of agricultural labour empower women? Insights from female labour contractors and workers in Northwest Syria. Journal of International Development 27: 898-916. doi:10.1002/jid.3007

Acharya, D. R., J. S. Bell, P. Simkhada, E. R., van Teijlingen, and P. R., Regmi. 2010. Women's autonomy in household decision-making: a demographic study in Nepal. Reprod Health 7. doi:10.1186/1742-4755-7-15

Agarwal, B. 2001. Participatory exclusions, community forestry, and gender: An analysis for south Asia and a conceptual framework. World Development 29: 1623-1648.

Alkire, S., R. Meinzen-Dick, A. Peterman, A. Quisumbing, G. Seymour, and A. Vaz. 2013. The women's empowerment in agriculture index. World Development 52: 71-91. doi:10.1016/j.worlddev.2013.06.007

Atreya, K. 2007. Pesticide use knowledge and practices: a gender differences in Nepal. Environ Res 104: 305-311. doi:10.1016/j.envres.2007.01.001

Bennett, L. 2005. Gender, caste, and ethnic exclusion In Nepal: Following the policy process from analysis to action. Paper presented at the New Frontiers of Social Policy, Arusha, $\mathrm{TZ}$.

Bhattarai, B., R. Beilin, and R. Ford. 2015. Gender, agrobiodiversity, and climate change: A study of adaptation practices in the Nepal Himalayas. World Development 70: 122-132. doi:10.1016/j.worlddev.2015.01.003

Bieri, S. 2014. New ruralities - old gender dynamics? A reflection on high-value crop agriculture in the light of the feminisation debates. Geographica Helvetica 69: 281-290. doi:10.5194/gh-69-281-2014

Boserup, E. 1970. Women's role in economic development. New York, NY: Earthscan Publications.

Central Bureau of Statistics (CBS). 2011. Nepal Living Standards Survey 2010/11 Vol. I. Kathmandu, Nepal: Central Bureau of Statistics.

Central Bureau of Statistics (CBS). 2012. Population and housing census 2011. Kathmandu, Nepal: Central Bureau of Statistics.

Chant, S. 2006. Re-thinking the "feminization of poverty" in relation to aggregate gender indices. Journal of Human Development 7: 201-220. doi:10.1080/14649880600768538 
Chapagain, B. K. 2015. Men's overseas migration and women's mobility and decision-making in rural Nepalese families. (Doctor of Philosophy), Australian National University, Canberra, Australia.

Chilibeck, G. 2004. Moving mountains through women's movements: the "feminization" of development discourse and practice in the Indian Himalayas. (Master of Arts), McGill University, Montreal, Canada.

Christie, M. E., M. Parks, and M. Mulvaney. 2016. Gender and local soil knowledge: Linking farmers' perceptions with soil fertility in two villages in the Philippines. Singapore Journal of Tropical Geography 37: 6-24. doi:10.1111/sjtg.12134

Cornwall, A. 2016. Women's empowerment: What works? Journal of International Development 28: 342-359. doi:10.1002/jid.3210

Deere, C. D. 2005. The feminization of agriculture? Economic restructuring in rural Latin America. Retrieved from Geneva, Switzerland: UNRISD.

Elmhirst, R. 2011. Introducing new feminist political ecologies. Geoforum 42: 129-132. doi:10.1016/j.geoforum.2011.01.006

Fortmann, L. 1996. Gendered knowledge: Rights and space in two Zimbabwe villages. In D. Rocheleau, B. Thomas-Slayter, and E. Wangari (Eds.), Feminist political ecology: Global issues and local experiences (pp. 211-223). London and New York: Routledge

Gaddis, I., and S. Klasen. 2014. Economic development, structural change, and women's labor force participation: a reexamination of the feminization $U$ hypothesis. Journal of Population Economics 27: 639-681. doi:10.1007/s00148-013-0488-2)

Gartaula, H. N., A. Niehof, and L. Visser. 2010. Feminization of agriculture as an effect of male out-migration: Unexpected outcomes from Jhapa District, Eastern Nepal. The International Journal of Interdisciplinary Social Sciences 5: 565-577.

Giri, K., and I. Darnhofer. 2010. Outmigrating men: A window of opportunity for women's participation in community forestry? Scandinavian Journal of Forest Research 25: 55-61. doi:10.1080/02827581.2010.506769

Goletti, F. 2013. TA 7762-NEP: Technical assistance for the preparation of the agricutlural development strategy, Asian Development Bank. Kathmandu, Nepal: Government of Nepal. https://www.adb.org/sites/default/files/project-document/78233/43447-022-neptacr-01.pdf. Accessed 20 Feb 2018. 
Hamilton, S., K.M. Moore, C. Harris, M. Erbaugh, I. Tanzo, C. Sachs, and L. Asturias de Barrios. 2005. Gender and IPM. In G. Norton, E. A. Heinrichs, G. C. Luther, and M. E. Irwin (Eds.), Globalizing integrated pest management: A participatory research process (pp. 263-289). Ames, Iowa: Blackwell Publishing.

International Labor Organization (ILO). 2017. ILOSTAT Database. https://data.worldbank.org/. Accessed 13 Jan 2018.

Jackson, C. 2007. Resolving risk? Marriage and creative conjugality. Development and Change 38: 107-129.

Kabeer, N. 2011. Between affiliation and autonomy: Navigating pathways of women's empowerment and gender justic in rural Bangladesh. Development and Change 42: 499528.

Kabeer, N., and L. Huq. 2010. The power of relationships: Love and solidarity in a landless women's organisation in rural Bangladesh. Oxford, UK: Institute of Development Studies.

Khadka, M., S. Karki, B.S.,Karky, R. Kotru, and K. B. Darjee. 2014. Gender equality challenges to the REDD+ initiative in Nepal. Mountain Research and Development 34: 197-207. doi:10.1659/mrd-journal-d-13-00081.1

Khatiwada, S., R. Howard, R. Horne, P. Huynh, G. Thebault, and S. Verick. 2017. Nepal labour market update. Kathmandu, Nepal: International Labor Organization.

Khatri, B. B. 2017. Utilization of remittance at household level: A case of Khanigaun Village of Resunga Municipality, Gulmi District. Nepalese Journal of Development and Rural Studies 14:13-20.

Lahiri-Dutt, K., and M. Adhikari. 2016. From sharecropping to crop-rent: Women farmers changing agricultural production relations in rural South Asia. Agriculture and Human Values 33: 997-1010. doi:10.1007/s10460-015-9666-z

Lama, A. S., S. Kharel, and T. Ghale. 2017. When the men are away: Migration and women's participation in Nepal's community forestry. Mountain Research and Development 37: 263-270. doi:10.1659/mrd-journal-d-16-00092.1

Lastarria-Cornhiel, S. 2006. Feminization of agriculture: Trends and driving forces. Washington, DC: World Bank. 
http://documents.worldbank.org/curated/en/655741468338477909/Feminization-ofagriculture-trends-and-driving-forces. Accessed 13 Dec 2017.

Lyon, S., T. Mutersbaugh, and H. Worthen. 2016. The triple burden: The impact of time poverty on women's participation in coffee producer organizational governance in Mexico. Agriculture and Human Values 34: 317-331. doi:10.1007/s10460-016-9716-1

Macdonald, M. 1995. Feminist economics: From theory to research. The Canadian Journal of Economics 28: 159-176.

Maharjan, A., S. Bauer, and B. Knerr. 2012. Do rural women who stay behind benefit from male out-migration? A case study in the hills of Nepal. Gender, Technology and Development 16: 95-123. doi:10.1177/097185241101600105

Maharjan, A., S. Bauer, and B. Knerr. 2013. International migration, remittances and subsistence farming: Evidence from Nepal. International Migration 51: e249-e263. doi:10.1111/j.1468-2435.2012.00767.x

Malapit, H., A. Quisumbing, R. Meinzen-Dick, G. Seymour, E. M. Martinez, J. Heckert, D. Rubin, A. Vaz, and K.M. Yount. 2019. "Development of the Project-Level Women's Empowerment in Agriculture Index (pro-WEAI).” IFPRI Discussion Paper 01796. Washington, DC: IFPRI.

Medeiros, M., and J. Costa. 2008. Is there a feminization of poverty in Latin America? World Development 36:115-127. doi:10.1016/j.worlddev.2007.02.011

Meinzen-Dick, R., D. Rubin, M. Elias, A. A. Mulema, and E. Myers. 2019. “Women’s Empowerment in Agriculture: Lessons from Qualitative Research.” IFPRI Discussion Paper 01797. Washington, DC: IFPRI.

Mollett, S. 2018. Environmental struggles are feminist struggles: Feminist political ecology as development critique. In A. M. Oberhauser, J. L. Fluri, R. Whitson, and S. Mollett (Eds.), Feminist spaces: Gender and geography in a global context (pp. 155-187). New York, NY: Routledge.

Mu, R., and D. van de Walle. 2011. Left behind to farm? Women's labor re-allocation in rural China. Labour Economics 18: S83-S97. doi:10.1016/j.labeco.2011.01.009

Nightingale, A. 2006. The nature of gender: Work, gender, and environment. Environment and Planning D: Society and Space 24: 165-185. doi:10.1068/d01k 
Nightingale, A. 2011. Bounding difference: Intersectionality and the material production of gender, caste, class and environment in Nepal. Geoforum 42(2), 153-162. doi:10.1016/j.geoforum.2010.03.004

Norton, G., E.A. Heinrichs, G.C. Luther, and M.E. Irwin. 2005. Globalizing integrated pest management (First ed.). Oxford, UK: Blackwell Publishing.

O’Hara, C., and F. Clement. 2018. Power as Agency: A Critical Reflection on the Measurement of Women's Empowerment in the Development Sector. World Development 106: 111-23. doi.org/10.1016/j.worlddev.2018.02.002.

O’Reilly, K. 2006. “Traditional” women, “modern” water: Linking gender and commodification in Rajasthan, India. Geoforum 37: 958-972. doi:10.1016/j.geoforum.2006.05.008

Owusu-Afriyie, J., and E. Nketiah-Amponsah. 2014. An indvidual level test of the "feminization of poverty" hypothesis. Journal of Developing Socieities 30: 25-43. doi:10.1177/0169796X13516351

Pearce, D. 1978. The feminization of poverty: Women, work and welfare. The Urban and Social Change Review 11: 28-36.

Pouratashi, M., and H. Iravani. 2012. Farmers' knowledge of integrated pest management and learning style preferences: Implications for information delivery. International Journal of Pest Management 58: 347-353. doi:10.1080/09670874.2012.724468

Radel, C., B. Schmook, J. Mcevoy, C. Mendez, and P. Petrzelka. 2012. Labour migration and gendered agricultural relations: The feminization of agriculture in the Ejidal Sector of Calakmul, Mexico. Journal of Agrarian Change 12: 98-119.

Radel, C., B. Schmook, and C. Mendez. 2013. Gender, the household, and land change in southeastern Mexico. In C. Brannstrom and J. M. Vadjunec (Eds.), Land Change Science, Political Ecology, and Sustainability: Synergies and divergences (pp. 107-127). London; New York: Routledge.

Ramamurthy, P. 2010. Why are men doing floral sex work? Gender, cultural reproduction, and the feminization of agricutlure. Journal of Women in Culture and Society 35:397-424.

Rocheleau, D. E., B.P. Thomas-Slayter, and E. Wangari. 1996. Gender and environment: A feminist political ecology perspective. In D. E. Rocheleau, B. P. Thomas-Slayter, and E. Wangari (Eds.), Feminist Political Ecology: Global issues and local experiences (pp. 321). London;New York: Routledge. 
Rubin, D., C. Manfre, and K.N. Barrett. 2009. Promoting gender equitable opportunities in agricultural value chains: A handbook. Washington, DC: USAID. http://www.culturalpractice.com/wp-content/downloads/4-2009-16.pdf. Accessed 15 April 2017.

Saldana, J. 2016. An introduction to codes and coding. In The Coding Manual for Qualitative Researchers (pp. 1-40). London: SAGE Publications.

Slavchevska, V., S. Kaaria, and S.L. Taivalmaa. 2016. Feminization of agriculture in the context of rural transformations: What is the evidence? Washington, DC: The World Bank.

Su, W., T. Eriksson, L. Zhang, and Y. Bai. 2016. Off-farm employment and time allocation in on-farm work in rural China from gender perspective. China Economic Review 41: 34-45. doi:10.1016/j.chieco.2016.08.006

Sugden, F., N. Maskey, F. Clement, V. Ramesh, A. Philip, and A. Rai. 2014. Agrarian stress and climate change in the Eastern Gangetic Plains: Gendered vulnerability in a stratified social formation. Global Environmental Change 29 :258-269. https://doi.org/10.1016/j.gloenvcha.2014.10.008

Sunam, R. 2017. In search of pathways out of poverty: Mapping the role of international labour migration, agriculture and rural labour. Journal of Agrarian Change 17: 67-80. doi:10.1111/joac.12136

Tamang, S., K. P. Paudel, and K. K., Shrestha. 2014. Feminization of agriculture and its implications on food security in rural Nepal. Journal of Forest and Livelihood 12: 20-32.

Tiwari, P. C., and B. Joshi. 2015. Climate change and rural out-migration in Himalaya. Change and Adaptation in Socio-Ecological Systems 2(1), doi:10.1515/cass-2015-0002

UNData. 2017. Country profile: Nepal. http://data.un.org/CountryProfile.aspx?crName=Nepal. Accessed 15 Oct 2017.

United Nations Field Coordination Office (UNFCO). 2011. An overview of the midwestern region of Nepal. Nepalgunj, Nepal: UNFCO. http://un.org.np/sites/default/files/Nepal_Mid_Western_Region_Overview_Paper_0.pdf. Accessed 10 Nov 2017.

United States Agency for International Development (USAID). 2013. Feed the future Nepal zone of influence baseline report. Rockville, MD: Westat. http://pdf.usaid.gov/pdf_docs/pa00k7pq.pdf. Accessed 10 Nov 2017. 
United States Agency for International Development (USAID). 2014. Country development cooperation strategy summary: Fiscal year 2014-2018. Kathmandua, Nepal: USAID Nepal.https://www.usaid.gov/sites/default/files/documents/1861/CDCS\%20summary_Fin al.pdf. Accessed 12 Nov 2017.

United States Agency for International Development (USAID). 2018. IPM Innovation Lab Mission. https://ipmil.cired.vt.edu. Accessed 15 March 2018.

Van Houweling, E. 2015. "A good wife brings her husband bath water": Gender roles and water practices in Nampula, Mozambique. Society \& Natural Resources 29: 1065-1078. doi:10.1080/08941920.2015.1095377

Yabiku, S. T., V. Agadjanian, and A. Sevoyan, A. 2010. Husbands' labour migration and wives' autonomy, Mozambique 2000-2006. Popul Stud (Camb) 64: 293-306. doi:10.1080/00324728.2010.510200

Zhang, L., S. Rozelle, C. Liu, S. Olivia, A. de Brauw, and Q. Li. 2006. Feminization of agriculture in China: Debunking the myth and measuring the consequence of women participation in agriculture. Washington, DC: World Bank. https://openknowledgeworldbank-org.ezproxy.lib.vt.edu/handle/10986/9103. Accessed 25 March 2017.

Zselecky, L., M.E. Christie, and J. Haleegoah. 2012. Embodied livelihoods and tomato farmers' gendered experience of pesticides in Tuobodom, Ghana. Gender, Technology and Development 18: 249-274. doi:10.1177/0971852414529483 
Table 1: Number of interview and FGD participants, disaggregated by sex and migrant status

\begin{tabular}{|l|c|c|c|}
\hline \multicolumn{1}{|c|}{ DATA COLLECTION METHOD } & FEMALE & MALE & TOTAL \\
\hline Key informant interviews & $\mathbf{3}$ & $\mathbf{8}$ & $\mathbf{1 1}$ \\
\hline Household interviews & $\mathbf{3 7}$ & $\mathbf{2 0}$ & $\mathbf{5 7}$ \\
\hline Migrant household member & 23 & 10 & 33 \\
\hline Non-migrant household member & 14 & 10 & 24 \\
\hline Focus group discussion & $\mathbf{2 5}$ & $\mathbf{1 6}$ & $\mathbf{4 1}$ \\
\hline \multicolumn{1}{|c|}{ TOTAL } & $\mathbf{6 5}$ & $\mathbf{4 4}$ & $\mathbf{1 0 9}$ \\
\hline
\end{tabular}




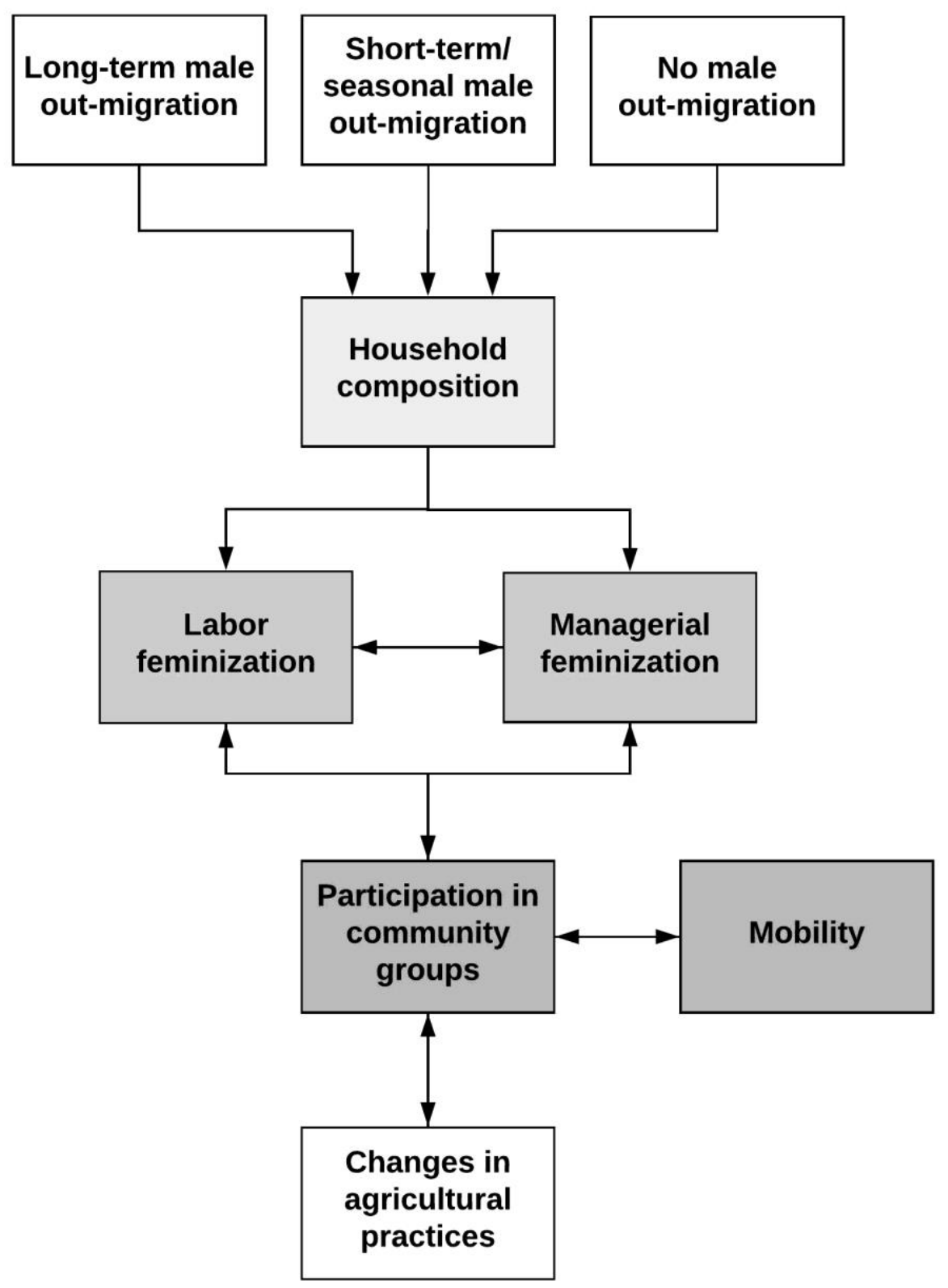

Figure 1: Conceptualization of the feminization of agriculture in study 


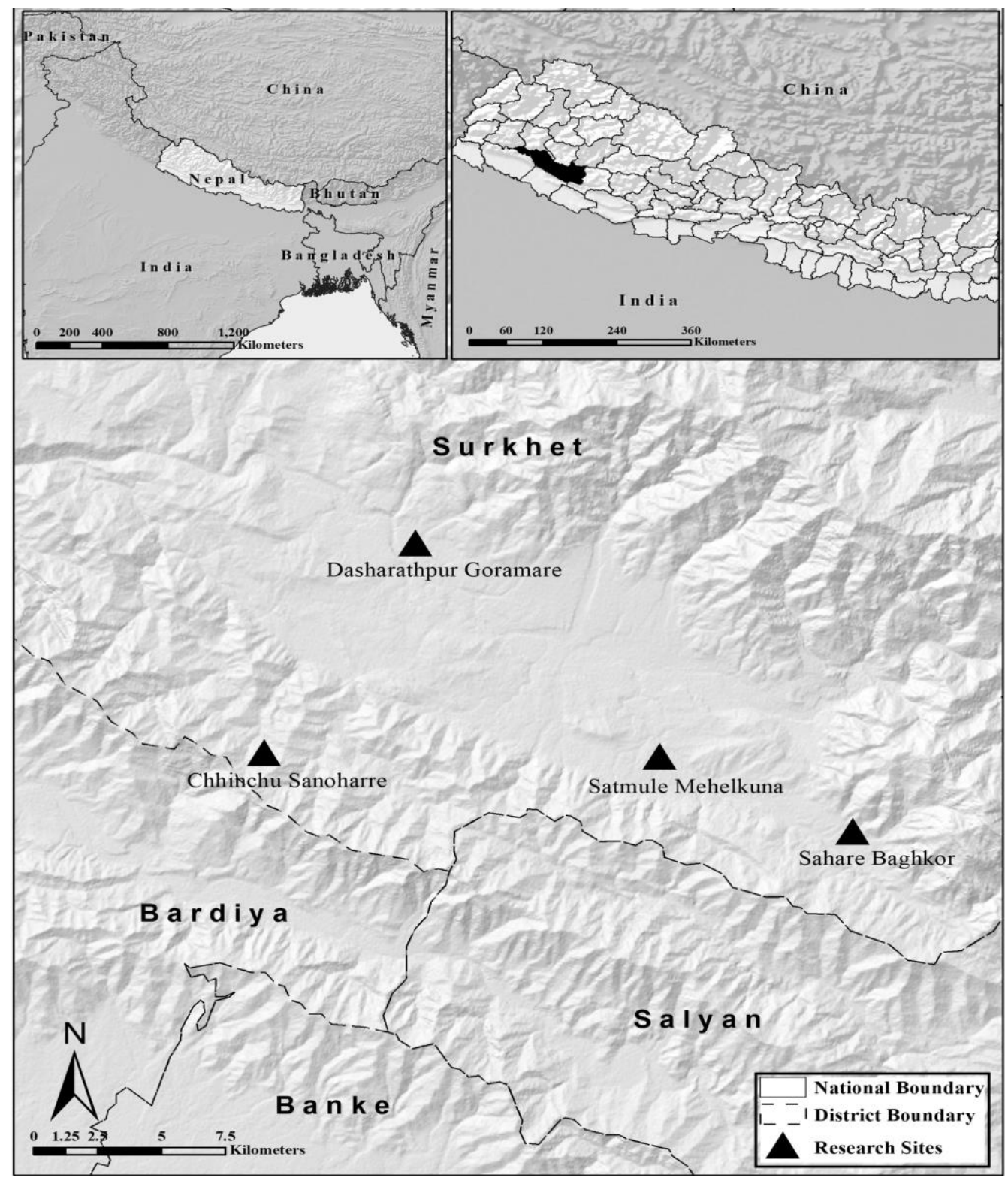

Figure 2: Nepal, the Surkhet District, and the four research sites 


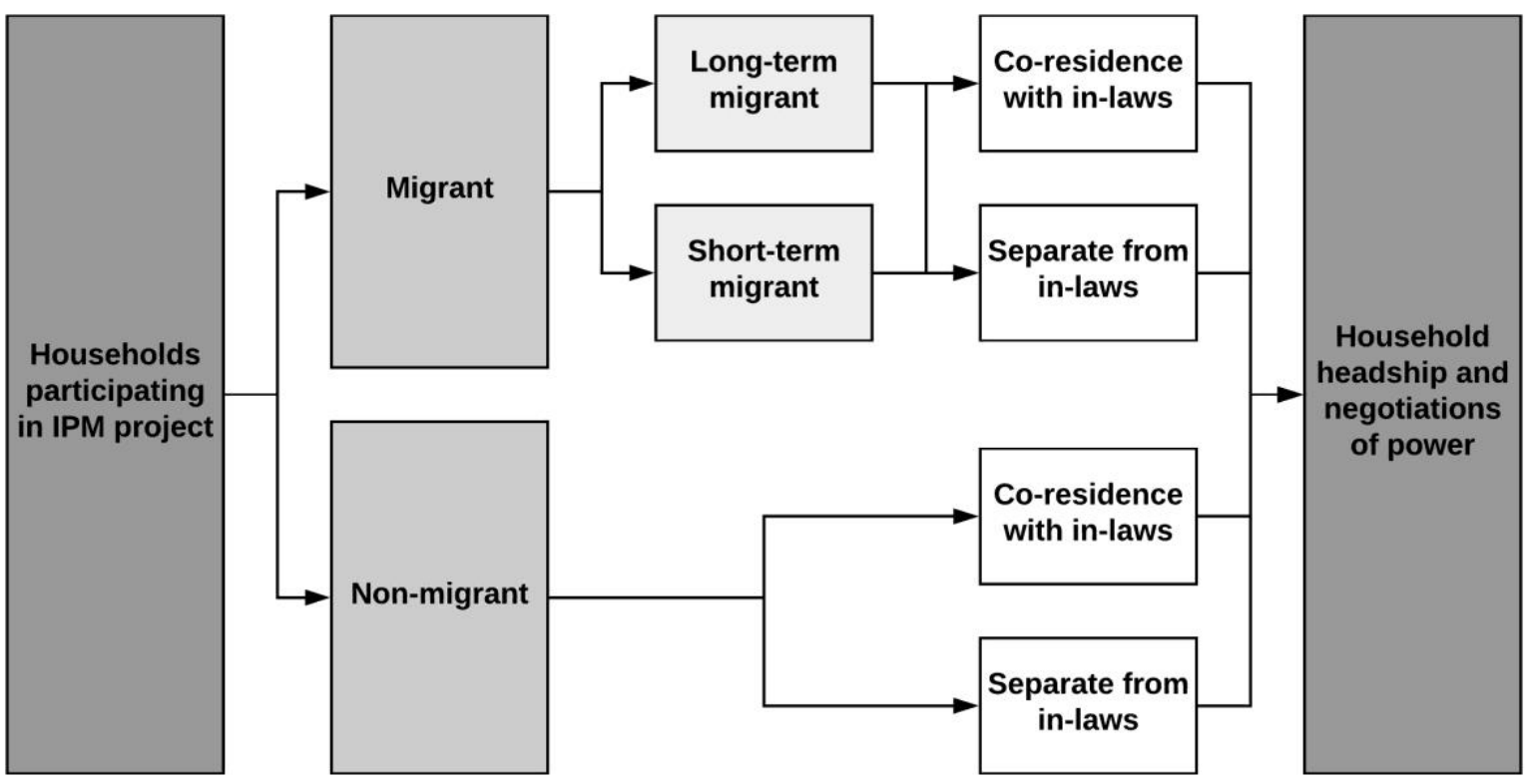

Figure 3: Differences in household composition and migration related to headship and power 


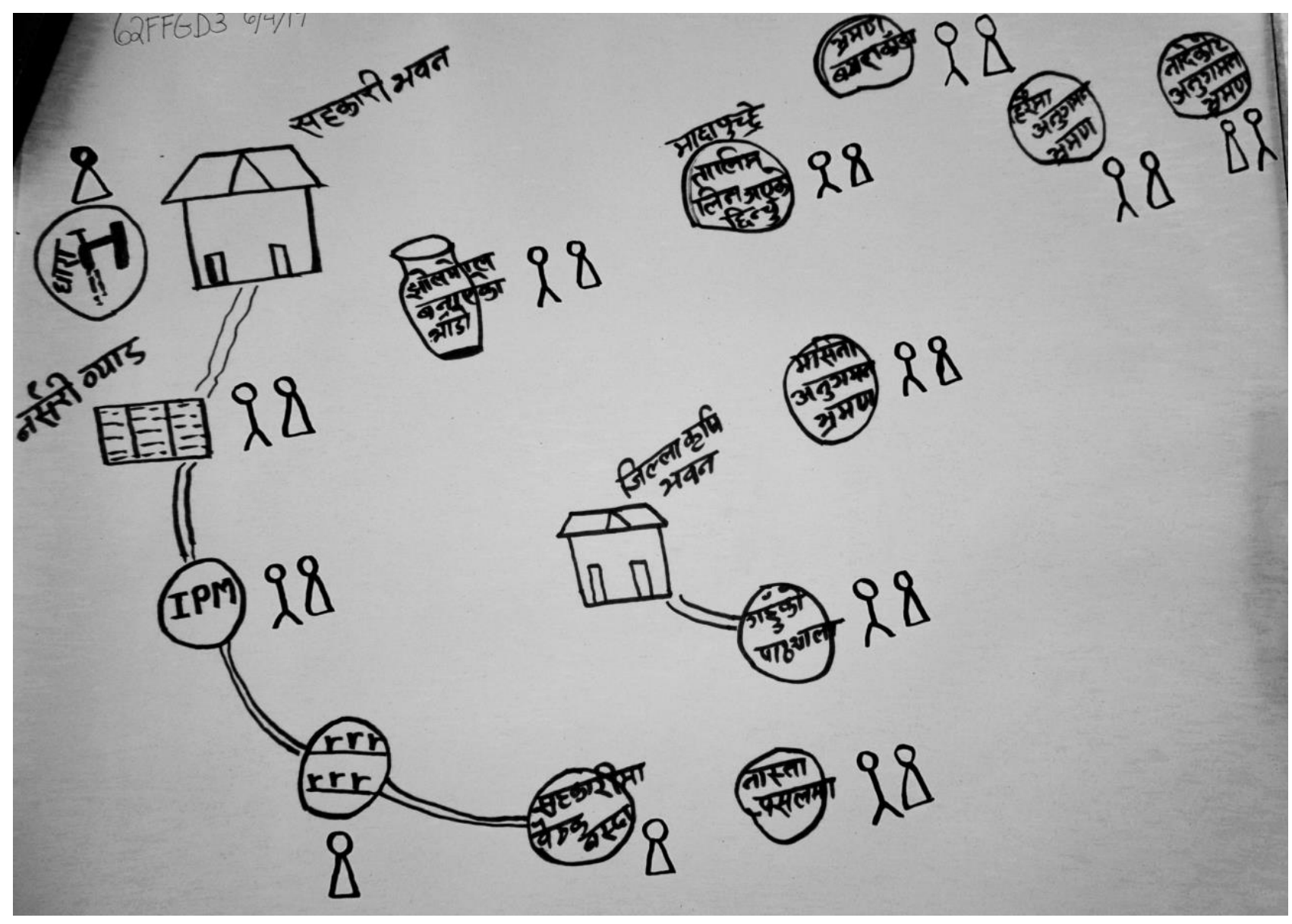

Figure 4: Participatory map from women's FGD, Dasharathpur Goramare 


\section{Appendix table A1:}

\begin{tabular}{|c|c|c|c|c|c|}
\hline \multicolumn{5}{|c|}{ Women's Empowerment in Agriculture Index (WEAI) Domains } & \\
\hline Control over income & $\begin{array}{l}\text { Decision-making over } \\
\text { production }\end{array}$ & $\begin{array}{l}\text { Resources, knowledge, and } \\
\text { skills }\end{array}$ & Time allocation & $\begin{array}{c}\text { Group participation and } \\
\text { leadership }\end{array}$ & \\
\hline $\begin{array}{l}\text { 1) Sole or joint } \\
\text { control over use of } \\
\text { income }\end{array}$ & $\begin{array}{l}\text { 1) Input in } \\
\text { productive decisions; } \\
\text { 2) Autonomy in } \\
\text { production }\end{array}$ & $\begin{array}{l}\text { 1) Ownership of productive } \\
\text { resources; 2) Access to } \\
\text { productive resources; } 3 \text { ) } \\
\text { Decision-making power over } \\
\text { productive resoures; 4) } \\
\text { Knowledge and skills about } \\
\text { productive resources }\end{array}$ & $\begin{array}{l}\text { 1) Time dedicated to } \\
\text { productive tasks (on } \\
\text { farm); 2) Time } \\
\text { dedicated to domestic } \\
\text { tasks (off-farm); 3) } \\
\text { Satisfaction with time } \\
\text { for leisure }\end{array}$ & $\begin{array}{l}\text { 1) Membership in economic } \\
\text { or social groups; 2) Comfort } \\
\text { speaking in public }\end{array}$ & \\
\hline \multicolumn{5}{|c|}{ Related FPE Themes } & \\
\hline $\begin{array}{l}\text { Gendered rights and } \\
\text { responsibilities }\end{array}$ & $\begin{array}{l}\text { Gendered knowledge/ } \\
\text { Rights and } \\
\text { responsibilities }\end{array}$ & $\begin{array}{l}\text { Gendered knowledge/ Rights } \\
\text { and responsibilities }\end{array}$ & $\begin{array}{l}\text { Gendered rights and } \\
\text { responsibilities }\end{array}$ & Gendered collective action & $\begin{array}{l}\text { Gender Dimensions } \\
\text { Framework (GDF) } \\
\text { Dimensions }\end{array}$ \\
\hline $\begin{array}{l}\text { (1) Do you have access } \\
\text { to your household } \\
\text { income for daily } \\
\text { needs? }\end{array}$ & $\begin{array}{l}\text { (3) How do you decide } \\
\text { what crop to plant? }\end{array}$ & $\begin{array}{l}\text { (2) Is IPM difficulty/easy for you } \\
\text { to learn and practice? If so, why? } \\
\text { If not, why? }\end{array}$ & $\begin{array}{l}\text { (3) What does a typical } \\
\text { day look like for you in } \\
\text { different seasons? }\end{array}$ & $\begin{array}{l}\text { (3) Are you involved in an } \\
\text { empowerment initiative? If so, } \\
\text { what is your role in this group? }\end{array}$ & (1) Access to assets \\
\hline $\begin{array}{l}\text { (3) How does male } \\
\text { out-migration affect } \\
\text { control over income? }\end{array}$ & $\begin{array}{l}\text { (3) How/why did you } \\
\text { decide to practice/not } \\
\text { practice IPM? }\end{array}$ & $\begin{array}{l}\text { (4) Who formally owns your } \\
\text { land? What does this formal } \\
\text { ownership permit or not permit? }\end{array}$ & $\begin{array}{l}\text { (3) Has this changed } \\
\text { since practicing IPM? }\end{array}$ & $\begin{array}{l}\text { (2) What are the benefits to } \\
\text { involvement in this initiative? }\end{array}$ & $\begin{array}{l}\text { (2) Beliefs and } \\
\text { perceptions }\end{array}$ \\
\hline $\begin{array}{l}\text { (3) Who purchases } \\
\text { resources/inputs to } \\
\text { practice IPM? }\end{array}$ & $\begin{array}{l}\text { (2) How does } \\
\text { autonomy in } \\
\text { agricultural production } \\
\text { change when the } \\
\text { household structure } \\
\text { changes? }\end{array}$ & $\begin{array}{l}\text { (3) Who attends trainings for } \\
\text { IPM and how is this decided? }\end{array}$ & $\begin{array}{l}\text { (2) What do you wish } \\
\text { you had more time to do? }\end{array}$ & $\begin{array}{l}\text { (3) What is your role in your } \\
\text { farmer group? }\end{array}$ & $\begin{array}{l}\text { (3) Practices and } \\
\text { participation }\end{array}$ \\
\hline $\begin{array}{l}\text { (5) How do you decide } \\
\text { to take out a loan? }\end{array}$ & $\begin{array}{l}\text { (5) Who has power in } \\
\text { deciding how you } \\
\text { manage your land? }\end{array}$ & $\begin{array}{l}\text { (2) How did you decide to } \\
\text { continue using IPM over several } \\
\text { seasons? }\end{array}$ & $\begin{array}{l}\text { (3) What do you do when } \\
\text { you finish all of your } \\
\text { farm and household } \\
\text { duties? }\end{array}$ & $\begin{array}{l}\text { (1) Does your involvement in } \\
\text { your famer group connect you } \\
\text { to resources you otherwise } \\
\text { would not have access to? }\end{array}$ & $\begin{array}{l}\text { (4) Laws, legal rights, } \\
\text { policies, and institutions }\end{array}$ \\
\hline $\begin{array}{l}\text { (3) Who saves in the } \\
\text { cooperative? }\end{array}$ & $\begin{array}{l}\text { (1) Can you make } \\
\text { decisions about your } \\
\text { land without } \\
\text { permission? }\end{array}$ & & $\begin{array}{l}\text { (3) How does leisure time } \\
\text { differ between men and } \\
\text { women? }\end{array}$ & $\begin{array}{l}\text { (3) How has your comfort in } \\
\text { public speaking changed with } \\
\text { your involvement in the farmer } \\
\text { group? }\end{array}$ & (5) Power \\
\hline
\end{tabular}

